\title{
Citizen-Centered Reporting: Assessing Popular Financial Reporting Practice in Italian Decentralized Governments
}

\author{
Carla Del Gesso ${ }^{1} \&$ Luca Romagnoli $^{1}$ \\ ${ }^{1}$ Department of Economics, University of Molise, Campobasso, Italy \\ Correspondence: Carla Del Gesso, Department of Economics, University of Molise, Campobasso, 86100, Italy. \\ E-mail: carla.delgesso@unimol.it
}

Received: December 5, 2019

Accepted: January 1, $2020 \quad$ Online Published: January 13, 2020

doi:10.5539/ijbm.v15n2p1

URL: https://doi.org/10.5539/ijbm.v15n2p1

\begin{abstract}
Given their proximity to citizens, Decentralized Governments (DGs) need to perform and report their activities from a citizen-centered perspective to improve transparency and accountability. The literature addressing reporting for citizens is piecemeal, and there is a dearth of studies that systematically analyze country experiences of popular reporting. To contribute to bridging this gap, this article provides an assessment of popular financial reporting practices in 370 Italian DGs from different perspectives. The authors evaluated the accessibility and readability of popular reports using simple, yet insightful quantitative measures. The results highlighted that Italian popular financial reporting practices are at an early stage of implementation. Popular reporting appears to be more difficult to implement in smaller municipalities than other levels of government. This research emphasizes citizen-centered reporting to support citizen-centered governance and accountability, suggesting that popular reporting practices in DGs need to increase; an improvement of the accessibility and readability of documents is also advisable to foster their usage. Greater and better popular reporting practices in DGs are needed to encourage citizen participation in the democratic processes of public governance in order to allow for better government performance results.
\end{abstract}

Keywords: popular financial reporting, citizen-centered reporting, public accountability, public governance, decentralized governments

\section{Introduction}

Citizens are key interlocutors of public administrations as they represent the core recipients of services, the main funders (as taxpayers) of activities, and are the electors of government leaders (Bingham et al., 2005; Osborne et al., 2013). Over recent decades, the public administration-citizen relationship has progressively evolved from a unidirectional rapport to a bidirectional interaction, as citizens have assumed both the role of active participants in governance processes and that of service co-producers (e.g., Vigoda, 2002; Roberts, 2004; Holzer \& Kloby, 2005; Kasymova \& Schachter, 2014; Bovaird et al., 2016; Thomas, 2017). Indeed, citizens are increasingly aware of the efficiency and effectiveness of public services; they are able to perceive and assess the quality and performance of government actions (Cohn Berman, 2008; Holzer et al., 2009; Van Ryzin \& Charbonneau, 2010). Hereupon, citizens demand not only better service provision but also effective governance of scarce public funds and greater evidence of government performance in order to improve their trust in politicians and public administrators (Bovaird \& Löffler, 2003). In other words, public administration outcomes should be of a suitable value, and thus an exchange for the sacrifice citizens have made through the paying of taxes. This implies that policy makers and public managers, who are accountable for efficiently spending public funds, should act in the public interest by conforming and reporting their behavior to the citizenry. Indeed, acting in the public interest means that governance is centered around performing sustainable, valuable outcomes for citizens, i.e. providing utilities for the administered community (Benington \& Moore, 2011; Bryson et al., 2014; Denhardt \& Denhardt, 2015). In addition, reporting performance results to citizens contributes to ensuring transparency, legitimacy and confidence in public policies and behavior, by enhancing democracy and public accountability (Melitski \& Manoharan, 2014; Van de Walle \& Cornelissen, 2014). However, effective public accountability is increasingly based on accessible, open government data and popular, understandable information which are both necessary for citizens to assess performance and judge the suitability of the outcomes achieved (Lourenço, 2015; Yusuf et al., 2017).

On the basis of these arguments, popular reporting practices took root in North America in the early 1990s, 
aiming at informing the general public about the financial performance of central and local governments, by providing user friendly reports presented in different forms (Sharp et al., 1998; Lee, 2006; Clay, 2007; Yusuf \& Jordan, 2015; Biancone et al., 2016a). Indeed, popular reports (or popular financial reports) express the technical accounting information contained in traditional annual financial reports in simplified language and a shortened version for a lay audience, such as citizens or other interested actors who are not familiar with accountancy (Kloby, 2009; Yusuf et al., 2013). Currently, these reports appear to be widespread solely in the contexts of local government in the US, Canada and Australia (Stanley et al., 2008; Yusuf et al., 2013). In addition, recent studies have analyzed single, popular reporting experiences that have emerged within the municipalities of the European area (Barbera et al., 2016; Biancone et al., 2016a). However, so far, scholars have not given great attention to the study of popular financial reporting (Biondi \& Bracci, 2018). In particular, the existing literature addressing performance reporting for citizens is piecemeal and there is a dearth of discourse concerning popular financial reporting practices and the accessibility and understandability of the various forms adopted.

The aforesaid scenario provides the background and justification for the present research. Accordingly, the study draws on the reasoning that the performance reporting systems of the different levels of decentralized government (DG) (the regions, provinces, municipalities and other local authorities), given their close proximity to citizens, should disclose easily understandable and accessible information about their performance to ensure accountability to their citizens. Since empirical studies analyzing systematic country experiences of popular reporting are lacking, this article contributes to the bridging of this gap by providing the current practice of popular financial reporting in Italian regional and local governments. It aims to explore and assess this practice to determine the extent to which popular financial reports are publicly available, accessible and comprehensible for citizens. More precisely, the study focuses on the Simplified Report for Citizens (SRC) - a special form of popular financial reporting recently established in Italy - and evaluates whether it is easily accessible and readable for citizens.

The SRC is a citizen-based financial document which became compulsory in Italian regional governments, provincial governments and municipalities with the recent accounting harmonization reform (decree no. 118/2011, paragraph 11, subsection 2; and subsequent modifications and additions). According to this law, which encourages public accountability (Manes Rossi, 2016), the SRC must contain a summary of the financial statement data. These data highlight the human and instrumental financial resources used in pursuing the various institutional aims and the results achieved vis-à-vis the quality of public services provided to citizens. All Italian regions and local governments must prepare an SRC and make it publicly available in their official website (in the "transparency administration" section, under the heading "reporting", together with other financial reporting documents). Indeed, the subsequent decree no. 33/2013 on public administration publicity and transparency, while highlighting changes in the public administration-citizen relationship, reiterates that citizens have the right to know what a public administration does and how it does it. For this reason, this decree states clearly that public administrations must publish annual financial data in a concise, aggregated and simplified form by using graphic representations, in order to ensure full accessibility and comprehensibility (decree no. 33/2013, paragraph. 29). Accordingly, the SRC aims to make financial reporting data easier and more understandable through an appealing representation of income and expenses, thus sharing data with and involving citizens who have a right and a duty to monitor public resource use. However, the legislation does not provide operating guidelines or a template for the preparation of the report, allowing Italian DGs discretion in deciding what information is to be included.

In this study, we assess the practice of producing SRCs in Italian DGs by examining the official websites of all 20 regions; all 107 provinces or equivalent territorial subdivisions; all 45 municipalities with a population of over 100,000; and a sample of 198 municipalities with a population of less than 100,000. Consequently, we analyze the accessibility and understandability of published SRC documents. The focus on SRCs is aimed at answering the following research questions:

$R Q_{1}$ : To what extent is the practice of popular financial reporting common in Italian DGs?

$R Q_{2}$ : Are popular reports easily obtainable by citizens?

$R Q_{3}$ : Are popular reports easily readable?

The research is motivated by the increasing citizen demand for transparent information and accountability that is essential to improve the efficient use of public financial resources, prevent corruption and enhance trust in governments at a time of severe public money constraint. The findings may provide a stimulus both to public administrators to implement or improve popular financial reporting practices and to scholars to increase popular reporting research in domestic contexts. The article continues with the following section 2 that sets out the conceptual framework adopted for this study. The subsequent section 3 explains the methodologies designed to address the research questions. Following this, the research results are presented in section 4 . The section 5 
discusses the findings and finally, the article concludes in section 6 , which presents the study limitations and implications of the research with some practical recommendations for developing effective popular reporting practices.

\section{Conceptual Framework}

\subsection{Focusing on (and Acting for) Citizens}

The focus on the complex relationship between public administrations and citizens has been emphasized in academic discourses by the theoretical debates concerning public governance, which has put forward a democratic and participative managerial framework for public sector governments (Kooiman \& Van Vliet, 1993; Kickert, 1995; Osborne, 2006; Stoker, 2006). Indeed, public governance studies have advanced the paradigms of traditional public administration (based on bureaucratic mechanisms) and new public management (NPM - based on market mechanisms), by rethinking ways of governing public funds and services (Lapsley, 2008; Lapsley, 2009) in a collaborative and interorganizational manner (Rhodes, 1996; Peters \& Pierre, 1998; Osborne, 2010; Cepiku, 2017). The ability of public policy to focus on performance outcomes (Arnaboldi et al., 2015), in order to meet the expectations of citizens and services users (in addition to the interests of other civil society actors), is at the core of public governance arguments (Anttiroiko et al., 2011; Pestoff, 2011; Grossi \& Steccolini, 2014). Within these arguments, public organization performance affects a society's environment beyond organizational boundaries. Accordingly, the performance principles of the " $3 \mathrm{Es}$ " (economization, efficiency and effectiveness) introduced by NPM, were integrated with the fundamental principles of the corporate governance concept, namely: openness (or transparency of disclosure); integrity (or honesty and completeness of reporting); and accountability (or responsibility for actions). These latter principles come from the Cadbury Report (Cadbury Committee, 1992) as forms of leadership and control of companies (Rhodes, 1996, p. 654). Indeed, the adoption of principles and concepts of corporate governance in public sector entities have gradually gained international acceptance both in literature and in practice (Hodges et al., 1996; Ryan \& Ng, 2000; Matei \& Drumasu, 2015), in order to promote a more effective and efficient governance of public resources. In particular, the principle of accountability to citizens and stakeholders (concerning the achieved outcomes) is considered among the main principles established by the International Framework for good governance in the public sector (IFAC \& CIPFA, 2014) issued by the International Federation of Accountants (IFAC) and the Chartered Institute of Public Finance and Accountancy (CIPFA). This framework, which intends to be a reference document for the development of national and sectoral governance codes, highlights the importance of implementing good practice in transparency, reporting and auditing in order to deliver effective accountability. Such effective accountability is concerned not only with reporting on actions completed, but also ensuring that stakeholders are able to understand how public administrations plan and perform their activities, due to increased transparency (IFAC \& CIPFA, 2014, p. 31).

It is very important to fill the information gap that exists between citizens and governments because this gap hinders effective citizen participation in governance processes (Jordan et al., 2016; Manes Rossi, 2019). As some studies have proven, providing popular financial data and making them accessible through websites and thus, helping to close the information gap, would increase accountability and public participation in governance (Jordan et al., 2016; Cohen et al., 2017). More in general, providing information about performance for citizens - as well as to all stakeholders - can encourage collaborative governance through the constructive engagement of people in public policy decision making and management (Emerson et al., 2012). Indeed, accessible, transparent performance information gives citizens the opportunity to enter into dialogue with their governments and thus empower their voice in governance processes to demand better outcomes from government (Rodriguez Bolivar et al., 2007; Porumbescu \& Grimmelikhuijsen, 2018). This is because, as highlighted by Van de Walle \& Cornelissen (2014), making performance information publicly available (through reporting tools) is the main public accountability mechanism by which administrations can explain and justify their behavior to citizens (see also Mack \& Ryan, 2007; Bovens et al., 2008; Stanley et al., 2008). Citizens need to be informed of how governments have spent taxpayers' money, e.g. for the provision of which public services; thus, financial and performance reporting represents the communication means that connects governments with their citizens allowing the latter to judge government performance (Peterman \& Lynskey, 2016). On the other hand, a greater level of accountability (in regard to stewardship of public money), as well as of transparency and legitimacy, stimulates governments to focus on the outcomes rather than on the processes and to be more efficient and responsive to performance (Bovens et al., 2014; Schillemans, 2016). In other words, it is important that the attention of public administration governance centers on citizens, who, as the voters of their elected leaders, are their "ultimate principals" (Andrews \& Shah, 2005, p. 166). In effect, in accordance with principal-agent theory, public administrators have the responsive role to act and perform as well as possible for their principals, and "reporting thus enhances the power of the principal over the agent" (Frederickson et al., 2012, p. 36; Denhardt \& Denhardt, 2015). Furthermore, a 
"more open, transparent, accountable and effective public governance" is one of the main challenges of modern governments (UN, 2014, p. 77). Indeed, citizens ask for more satisfactory information from their governments, and greater transparency and accountability are needed (Cucciniello \& Nasi, 2014; Yusuf \& Jordan, 2015). Hence, within this context it is essential that reporting tools focus on citizens and that the information they include is made accessible and easily readable for a public audience.

\subsection{Reporting for Citizens}

Financial reports can be considered the most public accountability tools provided by all levels of government on their transparency websites (Groff \& Pitman, 2004; Rodriguez Bolivar et al., 2007). However, as is well known, they provide a low level of accountability, as they are neither comprehensive (Blanco et al., 2011), nor easily readable for citizens. Therefore, simpler alternative reporting mechanisms are needed in order to provide transparent financial and accounting information about the use of public money for which governments are accountable to their citizens (Sharp et al., 1998; Stanley et al., 2008; Yusuf \& Jordan, 2015). Indeed, financial reports are complex technical documents which, for non-experts, are difficult to use, as highlighted by the Citizen-Centric Reporting (CCR) initiative of the Association of Government Accountants (AGA) (AGA, 2016). This AGA CCR initiative aims to simplify communication between governments and their citizens by encouraging governments to present their financial and performance information in forms accessible to the community (see also Peterman \& Lynskey, 2016). Moreover, AGA is not the only organization to recommend citizen-centered reporting, as several other government finance professional associations have encouraged popular reporting practices. In particular, in 1992, the Governmental Accounting Standards Board (GASB) issued a report that presented an overview of the different forms of popular financial reports specifically adopted by US local governments for citizens (Carpenter and Sharp, 1992). Furthermore, the Government Finance Officers Association (GFOA) encourages the US and Canadian governments to provide information disclosure on government financial activities in their internet websites, through a Comprehensive Annual Financial Report (CAFR) which must be supplemented with a condensed popular reporting version for citizens who are unfamiliar with accounting and financial reporting. According to the GFOA, which also provides recommendations for popular reporting best practices, popular reports of financial information can be presented in a variety of formats including consolidated or aggregated presentations (GFOA, 2006).

In summary, each of the above professional organizations has proposed a specific approach to popular reporting and has also issued reporting guidelines and awards for the best prepared documents (Harris et al., 2008; Biancone et al., 2019), such as the Popular Annual Financial Reporting (PAFR) Award Program of the GFOA. Despite such popular reporting fervor from professional bodies, in the literature there is a dearth of studies assessing country-specific popular financial reporting practices in decentralized governments. Research by Carpenter \& Sharp (1992) and its subsequent updating by Yusuf and colleagues (Yusuf et al., 2013) are among the main studies that have analyzed the local government practices of popular reporting in the US. In addition, Stanley and colleagues (Stanley et al., 2008) examined Community Financial Reports (CFR) in the context of Australian local government authorities. Yusuf and colleagues (Yusuf et al., 2013) highlighted the need for more studies on popular financial reporting. Very little research has addressed the development of popular reporting practices in Europe. However, some studies have addressed the relevance of the availability of financial regional government reporting on institutional websites for transparency purposes, also highlighting the need for more popular information to enable their use (Brusca \& Montesinos, 2006; Rodriguez Bolivar et al., 2007). In Italy, two single case studies were recently analyzed in terms of voluntary experiences, which concerned the municipality of Milan (Barbera et al., 2016) and Turin, the latter as a consolidated version for a local public group (Biancone et al., 2016a; Brescia, 2019). Therefore, no studies have systematically investigated the Italian practice of popular financial reporting in all domestic DGs, which is what the present research aims to do through an assessment of the accessibility and readability of the SRC documents. However, it must be highlighted that the SRC constitutes a new prescriptive tool which has only been recently introduced by the process of public accounting reform.

Popular reports can be effective useful accountability and transparency tools for citizens, because they are addressed, above all, at the general public with plain language and the use of graphs and tables that allow traditional financial reports to be simplified. Popular reports can play an educational role in the community and be easily accessible and understandable for the citizens they aim to serve (Jordan et al., 2017; Yusuf et al., 2017). However, as noted by Stanley, Jennings and Mack, local governments produce popular reports that not only vary considerably in terms of form and content, but also present a low level of financial disclosure due to the absence of style indications in their preparation (Stanley et al., 2008). In addition, popular financial reports do not automatically impact citizens (Kloby, 2009). Indeed, as revealed by Cohen, Mamakou and Karatzimas (2017), 
the citizen usage of popular reports is limited, although internet and information technologies could improve this use for accountability purposes and encourage the democratic participation of citizens. Accordingly, it is essential to make the reports accessible in government websites in order to increase their openness to an external audience and, in addition, improve citizens' trust in governments (Groff \& Pitman, 2004; Lourenço, 2015; Biancone et al., 2018). Furthermore, to encourage citizen use of popular reports, it is essential that these documents have a high readability level and as a consequence, they need to be written in an accessible style, as well as being visually attractive (Marsh et al., 2004; Yusuf \& Jordan, 2012).

Finally, it is appropriate to highlight here that the theme of popular reporting, despite the existence of few studies assessing the practice as discussed above, is currently arousing renewed interest in public sector accounting literature. This is because an emergent academic debate - regarding new challenges for the future of corporate reporting - has emphasized the need to provide a comprehensive performance disclosure, through more useful information for citizens and stakeholders demanding transparency and accountability, as shown by the growing literature on sustainability reporting and integrated reporting (e.g., Baboukardos \& Rimmel, 2016; Dumay et al., 2016; Adams, 2017; De Villiers \& Maroun, 2017; De Villiers \& Sharma, 2017). In particular, in the wake of the Integrated Reporting Framework (Integrated Reporting, 2013), the idea of combining the simple and short format of popular reporting with the comprehensive disclosure of integrated reporting has recently gained ground in the literature through "integrated popular reporting" (Cohen \& Karatzimas, 2015; Biancone et al., 2016b; Aversano et al., 2019; Manes Rossi, 2019). Indeed, in order to effectively satisfy the information needs of non-technical user groups, which citizens are, integrated popular reporting could represent the future structure of public sector reporting. As suggested by Cohen \& Karatzimas (2015), public sector reporting needs to reconcile popular reporting principles, which encourage governments to disclose in a user-friendly way the financial sustainability of their decisions, with those of integrated reporting which, on the other hand, encourage the disclosure of government impacts in their full dimensions (financial, social, environmental, etc.) (see also Aversano et al., 2019; Manes Rossi, 2019). Therefore, times are ripe for developing, with citizens closer to government levels, citizen-centered reporting mechanisms, as an alternative to traditional financial reporting. Popular reporting is a very current issue, since satisfying citizen information needs means that disclosures concerning government performance results should be complete and readily available and understandable for citizens. In this way, reporting for citizens can stimulate civic participation in governance.

\section{Data Collection and Methodologies}

This study aimed to assess the practice of producing SRCs in Italian DGs to determine the extent to which this form of popular financial reporting is published in their institutional websites and subsequently analyze its accessibility and readability for citizens. Following the subdivision of Italy into regions (the biggest administrative units), provinces (including equivalent territorial subdivisions), and municipalities (the smallest administrative units), our target population consisted, based on the official data of the Italian Institute of Statistics on date 1/1/2018, of 20 regions, 107 provinces, and 7,983 municipalities.

The first $R Q$ outlined in the Introduction was specifically connected to the data collection procedure, since it involved the determination of the (relative) frequency with which Italian DGs follow the practice of publishing popular financial reports in their websites. To this purpose, we decided to inspect the institutional websites of 370 Italian DGs: all 20 regions, all 107 provinces, and all 45 municipalities with a population over 100,000. Moreover, we collected a sample of 198 out of 7,938 municipalities with less than 100,000 inhabitants, in order to have a sampling error $e=5 \%$ in an (conservative) interval with a $90 \%$ confidence level for the relative frequency of the municipalities that publish online, at least one popular financial report.

We gathered and analyzed the SRC documents of the DGs for the last available year, in order to answer $R Q \mathrm{~s} 2$ and 3. It was not possible to consider homogeneous documents (relative to the same specific year) due to their heterogeneous availability on the internet websites of the DGs being assessed. The online access to the 370 Italian DG websites was carried out during February 2019.

In particular, the accessibility of SRC documents $\left(R Q_{2}\right)$ was assessed by means of the number of clicks needed to reach the document, starting from the homepage of the institutional website. The SRC was generally searched for within the special section called "transparency administration", under the heading "reporting", where it is usually published. Thus, this search for the document was repeated for all 370 Italian DGs assessed and for each of which the number of clicks required to obtain the document was manually counted. The collected data regarding the number of clicks were then processed by calculating some measures of descriptive statistics: minimum and maximum values, mean, and sample standard deviation. These calculations were carried out using Excel software. 
The readability of the SRCs $\left(R Q_{3}\right)$ was measured by means of the GulpEase index. The term "GulpEase" is an acronym, made up of the name of the Italian linguist group of the University of Rome that developed it, the Gruppo Universitario Linguistico Pedagogico (Gulp), and "Ease", referring to the ease with which a text can be read. The GulpEase index was formulated at the end of the 1980s in relation to the evaluation of text readability in the Italian language context (Lucisano \& Piemontese, 1988). We decided to employ this index because it was the first to be implemented directly for the assessment of the Italian language. For the examination of the difficult syntax of this language it is generally considered to be more reliable than other indexes and is traditionally the most used in the research of Italian documents and financial statements (Tonelli et al., 2012, p. 41; Allini et al., 2017). The formula is the following:

$$
g=89-l / 10+3 \cdot p
$$

Where:

$$
l=\frac{\text { no. of letters }}{\text { total no. of words }} \cdot 100, \text { and } p=\frac{\text { no. of phrases }}{\text { total no. of words }} \cdot 100
$$

Accordingly, the GulpEase index allowed us to assess the readability of the SRC documents collected, based on the total number of letters and phrases relative to the total number of words (length of words and sentences). This index ranges from " 0 " to " 100 ", where 0 expresses the lowest readability and 100 the maximum readability; this readability is evaluated in relation to three education levels for the reader. In particular (Lucisano \& Piemontese, 1988):

- $\quad$ an index value $\geq 40$ means that a document is easily readable by readers who have a high-school level of education;

- $\quad$ an index value $\geq 60$ means that a document is easily readable by readers who have a middle-school level of education;

- and an index value $\geq 80$ means that a document is easily readable by readers who have an elementary-school level of education.

The readability assessment of the SRC documents through the GulpEase index was performed with the help of the freely accessible online software, which is part of the "Farfalla project", at the Internet address: https://farfalla-project.org/readability_static/. The data collected were then processed by calculating some measures of descriptive statistics: minimum and maximum values, mean, and sample standard deviation. These calculations were carried out using Excel software.

\section{Analysis of Results}

This section presents the results of the study in response to the three research questions.

Table 1 shows the results in response to $R Q_{1}$ (to what extent is the practice of popular financial reporting common in Italian DGs?). As can be seen in this table, SRCs are not common at all in Italian DGs. The regions that published online at least one SRC document to date (February 2019) are only $35.0 \%$ (7 out of a total of 20) and the percentage of provinces and municipalities is even lower. Indeed, the percentage relating to the provinces is $15.9 \%$ (17 out of a total of 107), whereas that relating to large municipalities (with more than 100,000 inhabitants) is $24.4 \%$ ( 11 out of a total of 45 ). Lastly, the number of SRCs is almost nil in municipalities with less than 100,000 inhabitants; here, the active municipalities amount to only 5.1\% (10 out of the representative sample of 198) which correspond to smaller governments (almost all with less than 10,000 inhabitants) (Table 1). These data mean that the percentages of Italian DGs never having published an SRC document in their websites up to February 2019 are: $65.0 \%$ for the regions; $84.1 \%$ for the provinces; $75.6 \%$ for large municipalities; and $94.9 \%$ for those of a smaller size.

Table 1. Results for $\mathrm{RQ}_{1}$ : extent of the practice of popular financial reporting in Italian DGs

\begin{tabular}{lllll}
\hline $\begin{array}{l}\text { Decentralized } \\
\text { Governments (DGs) }\end{array}$ & $\begin{array}{l}\text { Total } \\
\text { number }\end{array}$ & $\begin{array}{l}\text { Sample size } \\
\text { (Ss) }\end{array}$ & $\begin{array}{l}\text { Number of } \\
\text { DGs producing } \\
\text { at least 1 SRC } \\
\text { (N.DGs) }\end{array}$ & $\begin{array}{l}\text { N.DGs / Ss } \\
\text { (\%) }\end{array}$ \\
\hline Regions & 20 & 20 (Total survey) & 7 & 35.0 \\
Provinces & 107 & 107 (Total survey) & 17 & 15.9 \\
Municipalities $\geq 100,000$ & 45 & 45 (Total survey) & 11 & 24.4 \\
Municipalities $<100,000$ & 7938 & 198 & 10 & 5.1 \\
\hline
\end{tabular}


Source: Our construction. Data analyzed from the results of the inspection of 370 Italian DG internet websites.

As highlighted in Figure 1, which provides a picture of the domestic practice of popular financial reporting based on their geographical distribution, there are five regions where no level of DG (neither region, nor provinces, nor municipalities) publishes any SRC documents in their respective websites. This is the case in the Valle d'Aosta in northern Italy, and in Molise, Campania, Basilicata and Sicily in the south. Southern Italy appears to be the area of the country where popular financial reporting practices are less common (16.7\%), whereas the percentages are a little higher in the north $(20.5 \%)$ and in the center $(26.5 \%)$. Yet, Figure 1 shows how these practices are very far from a systematic implementation in Italian DGs.

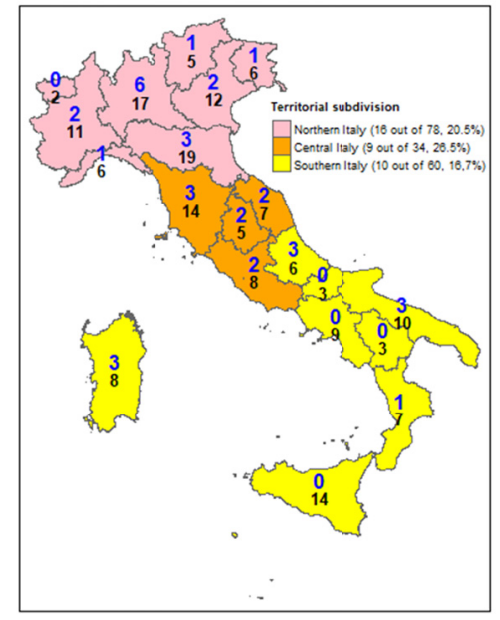

Figure 1. Total number of DGs presenting at least 1 SRC (blue numbers) and total number of DGs (black numbers) - Only Regions, Provinces and Municipalities $\geq 100,000$ inhabitants are considered (172

DGs)

Source. Our construction (through free statistical software R, packages tmap and tmaptools).

The results of the study in response to $R Q_{2}$ (are popular reports easily obtainable by citizens?) are synthetized in Table 2. Data in this table show that the online path to obtain each individual SRC document varies from a minimum of 3 clicks to a maximum of 9 clicks. Typically, it takes about 4 clicks to reach an SRC, by considering the following steps: DG website $\rightarrow$ transparency administration $\rightarrow$ reporting $\rightarrow$ SRC document. However, the number of clicks increases when there is a greater number of sub-sections in which each section of the online path is divided. This occurs in the case of the regions and provinces, as evidenced by the minimum values (4 clicks for both) and the maximum values ( 7 clicks for the regions and 9 for the provinces). In other words, at least 4 basic clicks are necessary to obtain the document with a maximum of up to 7 clicks for the regions and 9 for the provinces. Indeed, for one region, citizens and others interested people must follow 7 steps to gain access to the SRC document, while more than 5 clicks are needed on average (mean is 5.43). In addition, for one province, people must follow 9 steps to gain access to the SRC, whereas it takes on average nearly 6 clicks (mean is 5.82) to reach this document (Table 2). Conversely, for a couple of municipalities with more than 100,000 inhabitants, among the eleven which produced at least one SRC, the number of clicks to reach it is less than the four basic clicks; this happens because the popular version of the financial report is directly accessible from the homepage of the institutional website. Hence, the path consists of only 3 clicks (DG website/ popular reports/ SRC document). However, for large municipalities 5 clicks are needed on average (mean is 5.27), with a maximum of 7 clicks in two cases. For this reason, for these DGs the standard deviation (1.35), which expresses how far the data are from the mean, is the highest. However, in large municipalities popular financial documents are more readily available than in other DGs. In contrast, regarding the 10 municipalities; with less than 100,000 inhabitants that produce at least one SRC, none of them requires less than 5 clicks, as is shown by the minimum value in Table 2. This means that the online path to reach the SRCs on the websites of these DGs consists of at least five steps and on average it takes more than 6 clicks (mean is 6.30); hence, the SRC accessibility for smaller municipalities appears to be more difficult compared with the other DGs. In summary, the results described above suggest that better accessibility practices for popular financial reporting in Italian DGs are found 
in the case of large municipalities, followed by the regions and provinces; whereas, smaller municipalities rank last.

Table 2. Results for $\mathrm{RQ}_{2}$ : accessibility of SRCs on DGs websites, for DGs producing at least $1 \mathrm{SRC}$

\begin{tabular}{llllll}
\hline $\begin{array}{l}\text { Decentralized } \\
\text { Governments (DGs) }\end{array}$ & $\begin{array}{l}\text { Number of } \\
\text { DGs producing } \\
\text { at least 1 SRC } \\
\text { (N.DGs) }\end{array}$ & min & max & mean & Sd \\
\hline Regions & 7 & 4 & 7 & 5.43 & 0.98 \\
Provinces & 17 & 4 & 9 & 5.82 & 1.19 \\
Municipalities $\geq 100,000$ & 11 & 3 & 7 & 5.27 & 1.35 \\
Municipalities $<100,000$ & 10 & 5 & 8 & 6.30 & 1.06 \\
\hline
\end{tabular}

Source: Our construction. Data analyzed from the count results of the clicks needed to obtain each SRC document in the DG internet websites.

The results of the study in response to $R Q_{3}$ (are popular reports easily readable?) are presented in Table 3 . This table shows the content readability measurement of the collected SRCs, which was assessed by calculating the GulpEase index for each document. This index allowed us to quantify how difficult it is to understand the meaning of these documents. The higher the values of the index, the greater the readability of the documents i.e., the reader can have a lower level of education to understand it. The results showed that the SRCs assessed are not easy-to-read documents, given that the mean values of the GulpEase index range from 48.3 (in the case of the regions) to a maximum of 53.2 (in the case of the provinces) (Table 3). In particular, this means that the SRCs produced by the Italian DGs (regions, provinces and municipalities) require, on average, a high school level of education in order to be easily understood. Indeed, in no level of government did the value of the mean for the GulpEase index reach the threshold of $\geq 60$, which would indicate that the documents can be easily read by those with a middle/low level of education. However, by examining the maximum values of the index in Table 3, it can be seen that this threshold of 60 is reached in one case for the regions (max value equal to 60), and it is exceeded in one case for the provinces (max value of 74). Despite these higher values, in these two cases the documents also appeared to be difficult to read, as they mainly consist of technical tables. There are some Italian DGs whose popular financial reporting documents are exclusively composed of extremely complex tables without any explanatory information. As can be seen in Table 3, this mainly concerns municipalities with less than 100,000 inhabitants, where only two SRC documents had a number of words greater than 0 . The number of words in these two SRCs is also, on average, the lowest compared to the documents produced by the other DGs, as is also confirmed by the relative sample standard deviation. This means that the understandability of popular financial reports produced by small municipalities is very limited and is the worst of those assessed. Furthermore, in the case of the provinces, five produced popular documents that consist only of complex tables with no wording. Twelve provinces out of 17 produced SRCs with a number of words greater than 0 , although their readability level is very variable, as can be seen from the values that standard deviation assumes both for the GulpEase index and the number of words for the provinces (Table 3). The situation in the regions differs. Here, all 7 SRCs present a number of words greater than 0; and in the case of the municipalities with more than 100,000 inhabitants, only one entity produced a popular reporting document with no words.

It is important to consider that the presence of a higher number of words in SRCs does not necessarily mean a better readability; documents that are too long can be more difficult to read. This is precisely what occurs both in the case of the regions and the large municipalities, where the averages relating to the number of words $(3,648.9$ and 2,647.3 respectively) are higher than the other DGs; whereas, the respective GulpEase index means are lower (48.3 and 48.7 respectively) (Table 3). Indeed, there is one region (Piedmont) whose document consists of 12,197 words (where the GulpEase index $=43$ ), and one large municipality (Turin) whose document consists of 10,846 words (where the GulpEase index $=50$ ). Thus, despite the presence of these long documents, the GulpEase index is on average lower than that of the provinces and small municipalities. In summary, however, the readability of popular financial reports in Italian DGs is better in the large municipalities, regions and provinces compared to the smaller municipalities that exhibit the poorest practices. 
Table 3. Results for $\mathrm{RQ}_{3}$ : ease of reading of the last $\mathrm{SRC}$ available on $\mathrm{DG}$ websites

\begin{tabular}{|c|c|c|c|c|c|c|c|c|c|c|}
\hline & & & Gulp & ase in & & & No. & words & & \\
\hline $\begin{array}{l}\text { Decentralized } \\
\text { Governments (DGs) }\end{array}$ & $\begin{array}{l}\text { Number of } \\
\text { DGs producing } \\
\text { at least } 1 \text { SRC } \\
\text { (N.DGs) }\end{array}$ & $\begin{array}{l}\text { Last SRC: } \\
\text { number of } \\
\text { SRCs with no. } \\
\text { of words } \neq 0\end{array}$ & $\min$ & $\max$ & mean & Sd & $\min$ & $\max$ & mean & Sd \\
\hline Regions & 7 & 7 & 40 & 60 & 48.3 & 6.7 & 560 & 12197 & 3648.9 & 4011.3 \\
\hline Provinces & 17 & 12 & 36 & 74 & 53.2 & 9.2 & 84 & 2164 & 986.4 & 780.6 \\
\hline Municipalities $\geq 100,000$ & 11 & 10 & 39 & 57 & 48.7 & 5.7 & 259 & 10846 & 2647.3 & 3078.1 \\
\hline Municipalities $<100,000$ & 10 & 2 & 50 & 53 & 51.5 & 2.1 & 598 & 764 & 681.0 & 117.4 \\
\hline
\end{tabular}

Source: Our construction. Data analyzed from the results of GulpEase index calculation.

\section{Discussion}

This study has evaluated popular financial reporting practices in Italian DGs from different perspectives. First, we assessed the extent to which DGs publish different SRC presentations in their Internet websites; then, we determined the accessibility of these documents; and last, we measured the SRC readability for citizens (to whom they are addressed) and other possible government interlocutors.

The results shown in the previous section indicated that the publishing online of popular financial reports is not a common practice in Italian DGs. The diffusion of these reports among the levels of government closest to the citizens, such as the regions, provinces and municipalities in the Italian case, is very modest. In addition, the few popular reports produced are extremely variable in their form and information content, presumably due to the absence of a template and style indications for their preparation, as highlighted in the literature (Stanley et al., 2008). Indeed, the documents available differ greatly and consist of a variety of formats: some of them are year-end reports which aim to simplify the financial information contained in the final balance sheets; some represent simplified forms of financial forecasting reports; and finally, others are popular versions of consolidated financial statements, as in the case of the larger municipalities, such as Turin (Biancone et al., 2016a; Brescia, 2019) and Ferrara. Furthermore, popular financial reporting practices in Italian DGs are fragmented. Some governments have published a single document for only one specific year (many of which refer to the 2016 or 2017 financial year), others are more constant and have published their popular reports annually in the last two/three years; others are published in various versions (final, forecast and consolidated popular reports), as in the case of the large municipality of Perugia. On a positive note, some DGs have started implementing popular reporting in the last year; this may indicate that the development of popular financial reporting practices in Italian DGs is an ongoing process that currently is in its early stages. To date (February 2019 ), governments that produce at least one version of SRC are very rare (35\% of regions, $15.9 \%$ of provinces, $24.4 \%$ of large municipalities and $5.1 \%$ of those of a small size), despite its compulsory implementation (as recommended by decree no. 118/2011 on accounting harmonization and reinforced by decree no. 33/2013 on transparency); furthermore, in five of the twenty regions of the country no level of government practices popular reporting. However, the data is impressive, especially in the case of the small municipalities, which more than other levels of government should contemplate the citizen perspective, given their greater proximity to citizens. The dearth of resources, including the shortage of funds and personnel in smaller municipalities, in addition to the numerous legislative requirements introduced by the recent accounting harmonization reform (Manes Rossi, 2016), are possibly among the causes of these very limited popular reporting practices. Nevertheless, the Italian experience highlighted that the smallest municipalities (with less than 10,000 inhabitants) are the ones that, within the assessed sample of 198 municipalities with less than 100,000 inhabitants, are the most active in publishing SRCs on their websites; this sample included several governments with a population of over 10,000.

However, the findings also revealed that the popular reporting practices of these smaller municipalities are the worst compared to the other DGs in terms of accessibility and readability. Indeed, in order to access these popular reports, citizens and other interested groups must perform on average at least 6 steps in the online path on the relative website. This is relatively difficult when compared to the better access of reports in some of the larger municipalities, where access is granted after only three steps; this means that the reports are accessible directly from the homepage of the municipality website, without having to go through the various sections and subsections.

The Italian case provides an opportunity to emphasize that it is therefore essential to simplify the online procedure of access to popular reports so that even less experienced citizens can reach them immediately. It 
would be appropriate to promote these documents on the institutional homepage with a direct link or an appealing special section dedicated to reporting for citizens, in order to attract people to read them. This can help to improve the citizen use of popular reports that is currently limited at international level (Cohen et al., 2017; Yusuf et al., 2017). Furthermore, easy access to the disclosed data on the website portals can help governments improve their levels of openness and transparency towards their communities, supporting effective public accountability and participation (Groff \& Pitman, 2004; UN, 2014, p. 77; Lourenço, 2015). However, for both of these improvement purposes, it is equally essential that the disclosed available data is easily comprehensible and relevant for ordinary readers (Yusuf \& Jordan, 2012; Jordan et al., 2016).

Regarding the degree of readability of popular financial reporting in Italian DGs, which has been assessed in this study with the help of the GulpEase index, a low level of comprehensibility emerged from the findings. Indeed, the latter showed that the reports evaluated are not easy to read, and on average require a high level of education to be understood. In some cases, especially in smaller municipalities and some provinces, the documents mainly reported summary tables of income and expenditures, extracted from their traditional financial reports, without any effort to simplify the data and add explanatory information. In addition, some documents are files in Excel that only report graphics and tables, once again without the addition of descriptive information. Realistically, this kind of document can be interpreted as an ineffective attempt to merely comply with the law on transparency that requires Italian governments to publish their financial reports in a short, simple and concise form. Indeed, the absence of plain language to elucidate financial reporting data in these cases means that the documents are likely to be incomprehensible for most citizens and therefore of no use to them or other non-expert parties. This denotes that there is a current confusion in the Italian popular reporting experience, even though in some cases documents are prepared with greater care by including explanatory information on government finance. Accordingly, the Italian experience points out that, as highlighted in the literature, a more appropriate understandable style of text is needed to increase the ease with which popular reports can be read, in order to ensure full comprehensibility of the data for the general public (Marsh et al., 2004; Yusuf \& Jordan, 2012).

Reporting for citizens means providing comprehensive, useful data using simple language, which is able to satisfactorily inform the community about the effective, responsible government usage of public resources (Yusuf et al., 2013; Yusuf \& Jordan, 2015). It is important that citizens know how governments spend public funds for public services in the various policy areas (in which they intervene), such as health, public safety, education, economic development, culture, transportation, tourism, physical environment, etc. This is a crucial step along the governments' path towards citizen sharing and participation; citizens, as well as other stakeholders demanding transparency and accountability, have a right to be aware of the value created through the outcomes achieved by governments. However, a proper understanding of this value requires that governments not only provide information about government financial behavior but that it is integrated with non-financial information. This is important in order that the overall dimensions of sustainability disclosure (economic, social and environmental) can be considered, as suggested by the recent literature that has revived popular reporting matters by introducing integrated popular reporting discourses (e.g. Cohen \& Karatzimas, 2015; Aversano et al., 2019; Manes Rossi, 2019). However, in providing integrated information within popular reports, it is essential to maintain a short form and straightforward language, otherwise there is a risk that the readability may be poor if the documents are too long (Yusuf \& Jordan, 2012), although there is no fixed length to conform to (Biancone et al., 2019). Indeed, as emerged from the Italian case, one SRC document (in the case of the Piedmont region) which integrated financial information with social, environmental and governance information, but included a very high number of words, shows a low level of readability requiring a higher level of education.

\section{Conclusion}

This research replies to the call for more studies on popular financial reporting (Yusuf et al., 2013). It contributes to the body of knowledge on popular reporting by offering an assessment of the Italian experience of popular financial reporting in the diverse levels of government (regional and local). However, the study presents some limitations. Firstly, although the readability index used to assess the readability of popular financial reports appears to be the most suitable for assessing documents written in Italian language, it presents the limit to be a general-purpose measure of text readability. Moreover, the study does not focus on the structure and content of the reports and thus, does not analyze the informative categories popular reports disclose in order to be effective accountable documents. Lastly, the strengths and weaknesses of the best Italian DG popular reporting practices are not examined nor compared with those abroad.

Further studies are needed in order to develop and spread effective popular reporting practices at the international level. Furthermore, as the findings discussed in the previous section suggest, an increase of popular reporting implementation in decentralized governments is advisable; compliance with the law for the Italian case is also 
recommended. Indeed, a lesson from Italian experience is that popular financial reporting practices need greater diffusion and better implementation. Practitioners are also encouraged to promote the citizen usage of the documents by broadening their dissemination by the media, as well as by improving their accessibility on the official websites through an immediate, appealing link from the homepage. Likewise, a short, attractive and readable style of writing, through the adoption of clear language and an appropriate design for the average person with no financial reporting skills, is also recommended. This is because, greater and better popular reporting practices can foster effective accountability and transparency concerning government usage of public resources, that are crucial to enhance citizen participation in the democratic processes of public governance in order to allow for better government outcomes (Osborne, 2010; Bovens et al., 2014; Grossi \& Steccolini, 2014; Jordan et al., 2016). This could be especially relevant for the municipalities, even more so for those of a small size, where citizens are able to play an active role in the relationship with governments more easily, given the small size of the community. However, as the Italian experience revealed, popular financial reporting may be more difficult to implement in smaller municipalities than other DGs, due to the limited availability of human and financial resources. It is therefore likely that the dearth of these resources may require more efforts from these governments. Nevertheless, citizen-centered reporting should represent a rational commitment of DGs towards their communities. Indeed, in the public governance process, citizens are increasingly involved in the improvement of public policies and service performance that must be able to match their interests and expectations. Informing and educating citizens on government performance results allows their participation opportunities to be increased (Yusuf et al., 2017). Consequently, it is essential for the different levels of DG to support citizen-centered governance with citizen-centered reporting in order to encourage a democratic dialogue with the community, within a framework of mutual responsibility and trust. In essence, the potential for popular reporting to be an effective tool of communication and transparency is strictly connected to the government commitment to include the citizen voice in their governance and accountability processes.

\section{References}

Adams, C. (2017). Understanding integrated reporting: the concise guide to integrated thinking and the future of corporate reporting. Abingdon, UK: Routledge.

Allini, A., Ferri, L., Maffei, M., \& Zampella, A. (2017). From Accountability to Readability in the Public Sector: Evidence from Italian Universities. International Journal of Business and Management, 12(3), 27-35. https://doi.org/10.5539/ijbm.v12n3p27

Andrews, M., \& Shah, A. (2005). Citizen-Centered Governance: A new approach to public sector reform. In A. Shah (Ed.), Public Expenditure Analysis (pp. 153-181). Washington, DC: World Bank.

Anttiroiko, A. V., Bailey, S. J., \& Valkama, P. (Eds.) (2011). Innovations in Public Governance. Amsterdam, Netherlands: IOS Press BV.

Arnaboldi, M., Lapsley, I., \& Steccolini, I. (2015). Performance management in the public sector: The ultimate challenge. Financial Accountability \& Management, 31(1), 1-22. http://dx.doi.org/10.1111/faam.12049

AGA (Association of Government Accountants) (2016). Citizen-Centric Reporting (CCR) guidelines. Retrieved from

https://www.agacgfm.org/Resources/Performance-Accountability/CCR/How-to-Construct-a-CCR.aspx

Aversano, N., Polcini, P. T., Sannino, G., \& Agliata, F. (2019). Integrated Popular Reporting as a Tool for Citizen Involvement in Financial Sustainability Decisions. In J. Caruana, I. Brusca, E. Caperchione, S. Cohen, \& F. Manes Rossi (Eds.), Financial Sustainability of Public Sector Entities (pp. 185-205). Cham, Switzerland: Palgrave Macmillan. http://dx.doi.org/10.1007/978-3-030-06037-4_10

Baboukardos, D., \& Rimmel, G. (2016). Value relevance of accounting information under an integrated reporting approach: A research note. Journal of Accounting and Public Policy, 35(4), 437-452. https://doi.org/10.1016/j.jaccpubpol.2016.04.004

Barbera, C., Borgonovi, E., \& Steccolini, I. (2016). Popular Reporting and Public Governance: The Case of "Bilancio in Arancio" in Milan Municipality. In A. Hinna, L. Gnan, \& F. Monteduro (Eds.), Governance and Performance in Public and Non-Profit Organizations (pp. 3-30). Bingley, UK: Emerald Group Publishing Limited.

Benington, J., \& Moore, M. H. (Eds.). (2011). Public value: Theory and practice. New York, USA: Palgrave Macmillan.

Biancone, P. P., Secinaro, S., \& Brescia, V. (2016a). The Popular Financial Reporting: Focus on Stakeholders - 
The first European Experience. International Journal of Business and Management, 11(11), 115-125. http://dx.doi.org/10.5539/ijbm.v11n11p115

Biancone, P. P., Secinaro, S., \& Brescia, V. (2016b). Popular report and Consolidated Financial Statements in public utilities. Different tools to inform the citizens, a long journey of the transparency. International Journal of Business and Social Science, 7(1), 111-124.

Biancone, P. P., Secinaro, S., Brescia, V., \& Iannaci D. (2018). Communication and Data processing in Local Public Group: Transparency and Accountability. International Journal of Business and Management, 13(10), 20-37. https://doi.org/10.5539/ijbm.v13n10p20

Biancone, P., Secinaro, S., Brescia, V., \& Iannaci, D. (2019). The Popular Financial Reporting between Theory and Evidence, International Business Research, 12(7), 45-56. http://dx.doi.org/10.5539/ibr.v12n7p45

Bingham, L. B., Nabatchi, T., \& O'Leary, R. (2005). The new governance: Practices and processes for stakeholder and citizen participation in the work of government. Public Administration Review, 65(5), 547-558. https://doi.org/10.1111/j.1540-6210.2005.00482.x

Biondi, L., \& Bracci, E. (2018). Sustainability, Popular and Integrated Reporting in the Public Sector: A Fad and Fashion Perspective. Sustainability, 10(9), 3112. https://doi.org/10.3390/su10093112

Blanco, H., Lennard, J., \& Lamontagne, S. (2011). Annual reporting and accountability by municipalities in Canada: An empirical investigation. Accounting Perspectives, 10(3), 195-224. https://doi.org/10.1111/j.1911-3838.2011.00024.x

Bovaird, T., \& Löffler, E. (2003). Evaluating the quality of public governance: indicators, models and methodologies. International Review of Administrative Sciences, 69(3), 313-328. https://doi.org/10.1177/0020852303693002

Bovaird, T., Stoker, G., Jones, T., Loeffler, E., \& Pinilla Roncancio, M. (2016). Activating collective co-production of public services: influencing citizens to participate in complex governance mechanisms in the UK. International Review of Administrative Sciences, 82(1), 47-68. https://doi.org/10.1177/0020852314566009

Bovens, M., Goodin, R. E., \& Schillemans, T. (Eds.). (2014). The Oxford handbook of public accountability. Oxford, UK: Oxford University Press.

Bovens, M., Schillemans, T., \& Hart, P. T. (2008). Does public accountability work? An assessment tool. Public Administration, 86(1), 225-242. https://doi.org/10.1111/j.1467-9299.2008.00716.x

Brescia, V. (2019). The popular financial reporting: new accounting tool for Italian municipalities. Milan, Italy: FrancoAngeli.

Brusca, I., \& Montesinos, V. (2006). Are citizens significant users of government financial information? Public Money \& Management, 26(4), 205-209. http://dx.doi.org/10.1111/j.1467-9302.2006.00526.x

Bryson, J. M., Crosby, B. C., \& Bloomberg, L. (2014). Public value governance: Moving beyond traditional public administration and the new public management. Public Administration Review, 74(4), 445-456. https://doi.org/10.1111/puar.12238

Cadbury Committee. (1992). Report of the Committee on the Financial Aspects of Corporate Governance. London, UK: Gee and Co. Ltd. Retrieved from https://ecgi.global/sites/default/files//codes/documents/cadbury.pdf (accessed on 11 May 2019).

Carpenter, F., \& Sharp, F. (1992), Popular Reporting: Local Government Financial Reports to the Citizenry. Norwalk, USA: Governmental Accounting Standards Board of the Financial Accounting Foundation.

Cepiku, D. (2017). Collaborative governance. In T.R. Klassen, D. Cepiku, \& T. J. Lah (Eds.), The Routledge handbook of global public policy and administration. New York, USA: Routledge.

Clay, J. A. (2007). Popular reporting. In M. Lee (Ed.), Government Public Relations: A Reader (pp. 151-156). Florida, USA: CRC Press.

Cohen, S., \& Karatzimas, S. (2015). Tracing the future of reporting in the public sector: introducing integrated popular reporting. International Journal of Public Sector Management, 28(6), 449-460. https://doi.org/10.1108/IJPSM-11-2014-0140

Cohen, S., Mamakou, X. J., \& Karatzimas, S. (2017). IT-enhanced popular reports: Analyzing citizen preferences. Government Information Quarterly, 34(2), 283-295. https://doi.org/10.1016/j.giq.2017.04.003 
Cohn Berman, B. J. (2008). Involving the public in measuring and reporting local government performance. National Civic Review, 97(1), 3-10. https://doi.org/10.1002/ncr.198

Cucciniello, M., \& Nasi, G. (2014). Transparency for trust in government: How effective is formal transparency? International Journal of Public Administration, 37(13), 911-921. https://doi.org/10.1080/01900692.2014.949754

De Villiers, C., \& Maroun, W. (Eds.). (2017). Sustainability accounting and integrated reporting. Abingdon, UK: Routledge.

De Villiers, C., \& Sharma, U. (2017). A critical reflection on the future of financial, intellectual capital, sustainability and integrated reporting. Critical Perspectives on Accounting. In press. https://doi.org/10.1016/j.cpa.2017.05.003

Denhardt, J. V., \& Denhardt, R. B. (2015). The new public service: Serving, not steering (4th ed.). New York, USA: Routledge.

Dumay, J., Bernardi, C., Guthrie, J., \& Demartini, P. (2016). Integrated reporting: a structured literature review. Accounting Forum, 40(3):166-185. https://doi.org/10.1016/j.accfor.2016.06.001

Emerson, K., Nabatchi, T., \& Balogh, S. (2012). An integrative framework for collaborative governance. Journal of Public Administration Research and Theory, 22(1), 1-29. https://doi.org/10.1093/jopart/mur011

Frederickson, H. G., Smith, K. B., Larimer, C. W., \& Licari, M. J. (2012). The public administration theory primer (2nd ed.). USA: Westview Press.

GFOA (Government Finance Officers Association) (2006). Best practice. Popular Reporting of Financial Information (previously titled Preparing Popular Reports), approved by GFOA's Executive Board, February 2006. Retrieved from https://www.gfoa.org/popular-reporting-financial-information

Groff, J. E., \& Pitman, M. K. (2004). Municipal financial reporting on the world wide web: a survey of financial data displayed on the official websites of the 100 largest US municipalities. The Journal of Government Financial Management, 53(2), 20-30.

Grossi, G., \& Steccolini, I. (2014). Guest editorial: Accounting for public governance. Qualitative Research in Accounting \& Management, 11(2), 86-91. https://doi.org/10.1108/QRAM-04-2014-0031

Harris, J., McKenzie, K., \& Rentfro, R. (2008). Efforts and Accomplishments in Communicating Efforts and Accomplishments in Communicating with the Citizenry. Journal of Government Financial Management, 57(3), 36-40.

Hodges, R., Wright, M., \& Keasey, K. (1996). Corporate governance in the public services: Concepts and issues. Public Money \& Management, 16(2), 7-13. https://doi.org/10.1080/09540969609387915

Holzer, M., \& Kloby, K. (2005). Public performance measurement: An assessment of the state-of-the-art and models for citizen participation. International Journal of Productivity and Performance Management, 54(7), 517-532. https://doi.org/10.1108/17410400510622205

Holzer, M., Charbonneau, E., \& Kim, Y. (2009). Mapping the terrain of public service quality improvement: twenty-five years of trends and practices in the United States. International Review of Administrative Sciences, 75(3), 403-418. https://doi.org/10.1177/0020852309341330

IFAC \& CIPFA. (2014). International Framework: Good Governance in the Public Sector. Retrieved from https://www.cipfa.org/ /media/files/publications/standards/ifac/internationalframeworkgoodgovernanceinth epublicsectorifaccipfa2.pdf

Integrated Reporting. (2013). The international $<I R>$ framework. Retrieved from http://integratedreporting.org/wp-content/uploads/2015/03/13-12-08-THE-INTERNATIONAL-IR-FRAME WORK-2-1.pdf

Jordan, M. M., Yusuf, J. E., Berman, M., \& Gilchrist, C. (2017). Popular Financial Reports as Fiscal Transparency Mechanisms: An Assessment Using the Fiscal Transparency Index for the Citizen User. International Journal of Public Administration, 40(8), 625-636. https://doi.org/10.1080/01900692.2016.1186175

Jordan, M. M., Yusuf, J. E., Mayer, M., \& Mahar, K. (2016). What citizens want to know about their government's finances: Closing the information gap. The Social Science Journal, 53(3), 301-308. https://doi.org/10.1016/j.soscij.2016.04.007 
Kasymova, J. T., \& Schachter, H. L. (2014). Bringing participatory tools to a different level: A case study of local participatory practices in Kyrgyzstan. Public Performance \& Management Review, 37(3), 441-464. http://dx.doi.org/10.2753/PMR1530-9576370305

Kickert, W. (1995). Steering at a distance: A new paradigm of public governance in Dutch higher education. Governance, 8(1), 135-157. https://doi.org/10.1111/j.1468-0491.1995.tb00202.x

Kloby, K. (2009). Less is more: Exploring citizen-based financial reporting in local government. Journal of Public Budgeting, Accounting \& Financial Management, 21(3), 368-392. https://doi.org/10.1108/JPBAFM-21-03-2009-B002

Kooiman, J., \& Van Vliet, M. (1993). Governance and public management. In K.A. Eliassen \& J. Kooiman (Eds.), Managing public organization: lessons from contemporary European experience (pp. 58-72). London, UK: Sage Publications.

Lapsley, I. (2008). The NPM agenda: back to the future. Financial Accountability \& Management, 24(1), 77-96. https://doi.org/10.1111/j.1468-0408.2008.00444.x

Lapsley, I. (2009). New public management: The cruellest invention of the human spirit? Abacus, 45(1), 1-21. https://doi.org/10.1111/j.1467-6281.2009.00275.x

Lee, M. (2006). The history of municipal public reporting. International Journal of Public Administration, 29(4-6), 453-476. https://doi.org/10.1080/01900690500436982

Lourenço, R. P. (2015). An analysis of open government portals: A perspective of transparency for accountability. Government Information Quarterly, 32(3), 323-332. https://doi.org/10.1016/j.giq.2015.05.006

Lucisano, P., \& Piemontese, M. E. (1988). Gulpease: una formula per la predizione della difficoltà dei testi in lingua italiana. Scuola e Città, 3(31), 110-124.

Mack, J., \& Ryan, C. (2007). Is there an audience for public sector annual reports: Australian evidence?. International Journal of Public Sector Management, 20(2), 134-146. https://doi.org/10.1108/09513550710731490

Manes Rossi, F. (2016). Public sector accounting and Auditing in Italy. In I. Brusca, E. Caperchione, S. Cohen, \& F. Manes Rossi (Eds.), Public Sector Accounting and Auditing in Europe: The Challenge of Harmonization. (pp. 125-141). London, UK: Palgrave Macmillan.

Manes Rossi, F. (2019). New development: Alternative reporting formats: a panacea for accountability dilemmas?. Public Money \& Management, 1-4. https://doi.org/10.1080/09540962.2019.1578540

Marsh, T. L., Montondon, L. G., \& Daniels, J. (2004). Readability of award winning popular annual financial reports. Journal of Accounting \& Finance Research, 12(2), 32-39.

Matei, A., \& Drumasu, C. (2015). Corporate Governance and public sector entities. Procedia Economics and Finance, 26, 495-504. https://doi.org/10.1016/S2212-5671(15)00879-5

Melitski, J., \& Manoharan, A. (2014). Performance measurement, accountability, and transparency of budgets and financial reports. Public Administration Quarterly, 38(1), 38-70.

Osborne, S. P. (Ed.). (2010). The new public governance: Emerging perspectives on the theory and practice of public governance. Abingdon, UK: Routledge.

Osborne, S. P., Radnor, Z., \& Nasi, G. (2013). A new theory for public service management? Toward a (public) service-dominant approach. The American Review of Public Administration, 43(2), 135-158. https://doi.org/10.1177/0275074012466935

Osborne, S.P. (2006). The New public governance? Public Management Review, 8(3), 377-387. https://doi.org/10.1080/14719030600853022

Pestoff, V. (2011). New public governance and accountability: some jewels in a treasure chest. Lecture on May 3 , 2011 at the CIES program on Corporate Social Responsibility and Social Enterprise in Atlanta, Georgia. CIES Centro de Investigación de Economía y Sociedad, 91, 2-22.

Peterman, M. E., \& Lynskey, J. H. (2016). Transparency and Accountability through Public-Sector Reporting. The Journal of Government Financial Management, 65(4), 54-56.

Peters, B. G., \& Pierre, J. (1998). Governance without Government? Rethinking public administration. Journal of Public Administration Research and Theory, 8(2), 223-243. https://doi.org/10.1093/oxfordjournals.jpart.a024379 
Porumbescu, G. A., \& Grimmelikhuijsen, S. (2018). Linking Decision-Making Procedures to Decision Acceptance and Citizen Voice: Evidence from Two Studies. The American Review of Public Administration, 48(8), 902-914. https://doi.org/10.1177/0275074017734642

Rhodes, R.A.W. (1996). The new governance: governing without government. Political Studies, 44(4), $652-667$. https://doi.org/10.1111/j.1467-9248.1996.tb01747.x

Roberts, N. (2004). Public deliberation in an age of direct citizen participation. The American Review of Public Administration, 34(4), 315-353. https://doi.org/10.1177/0275074004269288

Rodriguez Bolivar, M. P., Caba Perez, C., \& Lopez Hernandez, A. M. (2007). E-Government and public financial reporting: the case of Spanish regional governments. The American Review of Public Administration, 37(2), 142-177. https://doi.org/10.1177/0275074006293193

Ryan, C., \& Ng, C. (2000). Public sector corporate governance disclosures: an examination of annual reporting practices in Queensland. Australian Journal of Public Administration, 59(2), 11-27. https://doi.org/10.1111/1467-8500.00148

Schillemans, T. (2016). Calibrating Public Sector Accountability: Translating experimental findings to public sector accountability. Public Management Review, 18(9), 1400-1420. https://doi.org/10.1080/14719037.2015.1112423

Sharp, F. C., Carpenter, F. H., \& Sharp, R. F. (1998). Popular financial reports for citizens. The CPA Journal, 68(3), 34.

Stanley, T., Jennings, N., \& Mack, J. (2008). An examination of the content of community financial reports in Queensland local government authorities. Financial Accountability \& Management, 24(4), 411-438. https://doi.org/10.1111/j.1468-0408.2008.00460.x

Stoker, G. (2006). Public value management: A new narrative for networked governance?. The American Review of Public Administration, 36(1), 41-57. https://doi.org/10.1177/0275074005282583

Thomas, J. C. (2017). Citizen, Customer, Partner. Engaging the Public in Public Management. New York, USA: Routledge.

Tonelli, S., Manh, K. T., \& Pianta, E. (2012). Making readability indices readable. In Proceedings of the First Workshop on Predicting and Improving Text Readability for target reader populations (pp. 40-48). Montreal, Canada: Association for Computational Linguistics.

UN (United Nations) (2014). E-Government Survey 2014: E-Government for the future we want. United Nations Department of Economic and Social Affairs. Retrieved from https://publicadministration.un.org/egovkb/Portals/egovkb/Documents/un/2014-Survey/E-GovComplete_Su rvey-2014.pdf

Van de Walle, S., \& Cornelissen, F. (2014). Performance reporting. In M. Bovens, R.E. Goodin, \& T. Schillemans (Eds.), The Oxford handbook of public accountability (pp. 441-455). Oxford, UK: Oxford University Press.

Van Ryzin, G. G., \& Charbonneau, E. (2010). Public service use and perceived performance: An empirical note on the nature of the relationship. Public Administration, 88(2), 551-563. https://doi.org/10.1111/j.1467-9299.2010.01820.x

Vigoda, E. (2002). From responsiveness to collaboration: Governance, citizens, and the next generation of public administration. Public Administration Review, 62(5), 527-540. https://doi.org/10.1111/1540-6210.00235

Yusuf, J. E, Jordan, M. M., Franklin, A. L., \& Ebdon, C. (2017). How Much Are Citizen Perceptions of Fiscal Accountability Influenced by Government Transparency, Information Access, and Participation Opportunities?. Public Finance and Management, 17(4), 369-394.

Yusuf, J. E., \& Jordan, M. M. (2012). Effective popular financial reports: The citizen perspective. Journal of Government Financial Management, 61(4), 45-49.

Yusuf, J. E., \& Jordan, M. M. (2015). Popular financial reports: Tools for transparency, accountability and citizen engagement. The Journal of Government Financial Management, 64(1), 12-17.

Yusuf, J. E., Jordan, M. M., Neill, K. A., \& Hackbart, M. (2013). For the people: Popular financial reporting practices of local governments. Public Budgeting \& Finance, 33(1), 95-113. https://doi.org/10.1111/j.1540-5850.2013.12003.x 


\section{Copyrights}

Copyright for this article is retained by the author(s), with first publication rights granted to the journal.

This is an open-access article distributed under the terms and conditions of the Creative Commons Attribution license (http://creativecommons.org/licenses/by/4.0/). 